University of Washington Tacoma

UW Tacoma Digital Commons

SIAS Faculty Publications

School of Interdisciplinary Arts and Sciences

2012

\title{
Sisters' Retiring Room From the North Family Dwelling, Mount Lebanon, New York, Ca. 1845
}

Julie Nicoletta

University of Washington Tacoma, jn@uw.edu

Follow this and additional works at: https://digitalcommons.tacoma.uw.edu/ias_pub

\section{Recommended Citation}

Nicoletta, Julie, "Sisters' Retiring Room From the North Family Dwelling, Mount Lebanon, New York, Ca. 1845" (2012). SIAS Faculty Publications. 715.

https://digitalcommons.tacoma.uw.edu/ias_pub/715

This Article is brought to you for free and open access by the School of Interdisciplinary Arts and Sciences at UW Tacoma Digital Commons. It has been accepted for inclusion in SIAS Faculty Publications by an authorized administrator of UW Tacoma Digital Commons. 


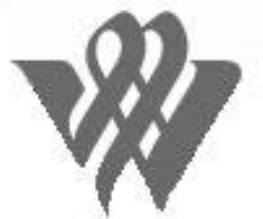

Sisters' Retiring Room from the North Family Dwelling, Mount Lebanon, New York, ca. 1845

Author(s): Tulie Nicoletta

Source: Winterthur Portfolio, Vol. 46, No. 2/3, Period Room Architecture in American Art Museums (Summer/Autumn 2012), pp. E37-E43

Published by: The University of Chicago Press on behalf of the Henry Francis du Pont Winterthur Museum, Inc.

Stable URL: http://www.jstor.org/stable/10.1086/668452

Accessed: 04-05-2017 19:54 UTC

JSTOR is a not-for-profit service that helps scholars, researchers, and students discover, use, and build upon a wide range of content in a trusted digital archive. We use information technology and tools to increase productivity and facilitate new forms of scholarship. For more information about JSTOR, please contact support@jstor.org.

Your use of the JSTOR archive indicates your acceptance of the Terms \& Conditions of Use, available at

http://about.jstor.org/terms

Henry Francis du Pont Winterthur Museum, Inc., The University of Chicago Press are collaborating with JSTOR to digitize, preserve and extend access to Winterthur Portfolio 


\title{
Sisters' Retiring Room from the North Family Dwelling, Mount Lebanon, New York, ca. 1845
}

\author{
Julie Nicoletta
}

The Sisters' Retiring Room at the Philadelphia Museum of Art is historically and architecturally significant, as it comes from the Mount Lebanon Shaker community, which served as the lead village for all of Shakerdom. The ministry, the head elders and eldresses, of Mount Lebanon created buildings, religious rituals, and social practices to serve as models for the other Shaker communities to follow. Furthermore, the room—one of only two that survive from the North Family Dwelling-offers a physical record not only of a nineteenth-century Shaker retiring room but also of the mid-twentieth-century interpretation of Shaker design.

$\mathrm{T}$ HE SISTERS' RETIRING ROOM is composed of elements from a room on the second floor of the North Family Dwelling at Mount Lebanon, New York (fig. 1). When the Philadelphia Museum of Art (PMA) commissioned a new study of this room in 2005 , the scope of work specifically requested research on the building from which the room came in addition to an examination of other Shaker period rooms installed in American museums. The PMA also wanted an assessment of the room's significance and accuracy, because, at the time, there was some discussion that the room would be moved and reinstalled in another part of the museum. To date, however, the room has remained where it was originally placed in 1976. The room and Shaker exhibit nearby may be reinstalled in the next three to five years but kept in their current location.

Julie Nicoletta is professor of art and architectural history and public history in the Interdisciplinary Arts and Sciences Program at the University of Washington, Tacoma.

The author would like to thank David Barquist, the H. Richard Dietrich Jr. Curator of American Decorative Arts at the Philadelphia Museum of Art, for initially asking me to review and assess the museum's Shaker Room. Thanks also go to Amelia Peck, Marica F. Vilcek Curator, American Wing, Metropolitan Museum of Art, for assistance in reviewing documents regarding the Met's Shaker room. Finally, a thank-you to Joan Johnson for alerting the author to the paint analysis work at Hancock Shaker Village.

(c) 2012 by The Henry Francis du Pont Winterthur Museum, Inc. All rights reserved. oo84-0416/2012/4623-0010\$10.00
In early 1973, Beatrice Garvan, then assistant curator in the museum's Department of American Art, negotiated this acquisition, including a built-in unit containing two cabinets and eight drawers, a pegboard, baseboards, two windows and their frames, door frames and their doors and transoms, four floor boards, and a radiator. The museum also acquired red-painted woodwork from the kitchen, including a baseboard, pegboard, door and frame from the north wall, as well as a ventilating window and shelf. These architectural elements were being sold by the Darrow School, a private preparatory school, which in 1929 had purchased many of the Church, Center, and North Families' buildings, including the main North Family Dwelling. Some of the dwelling houses functioned as dormitories for the school, although the North Family Dwelling was allowed to fall into disrepair until the Darrow School demolished it in 1973 .

The Sisters' Retiring Room is significant, as it comes from the Mount Lebanon Shaker community, which served as the lead village for all of Shakerdom. The ministry, the head elders and eldresses, of Mount Lebanon created buildings, religious rituals, and social practices to serve as models for the other Shaker communities to follow. Furthermore, the room-one of only two that survive from the North Family Dwellingoffers a physical record not only of a nineteenthcentury Shaker retiring room but also of the 


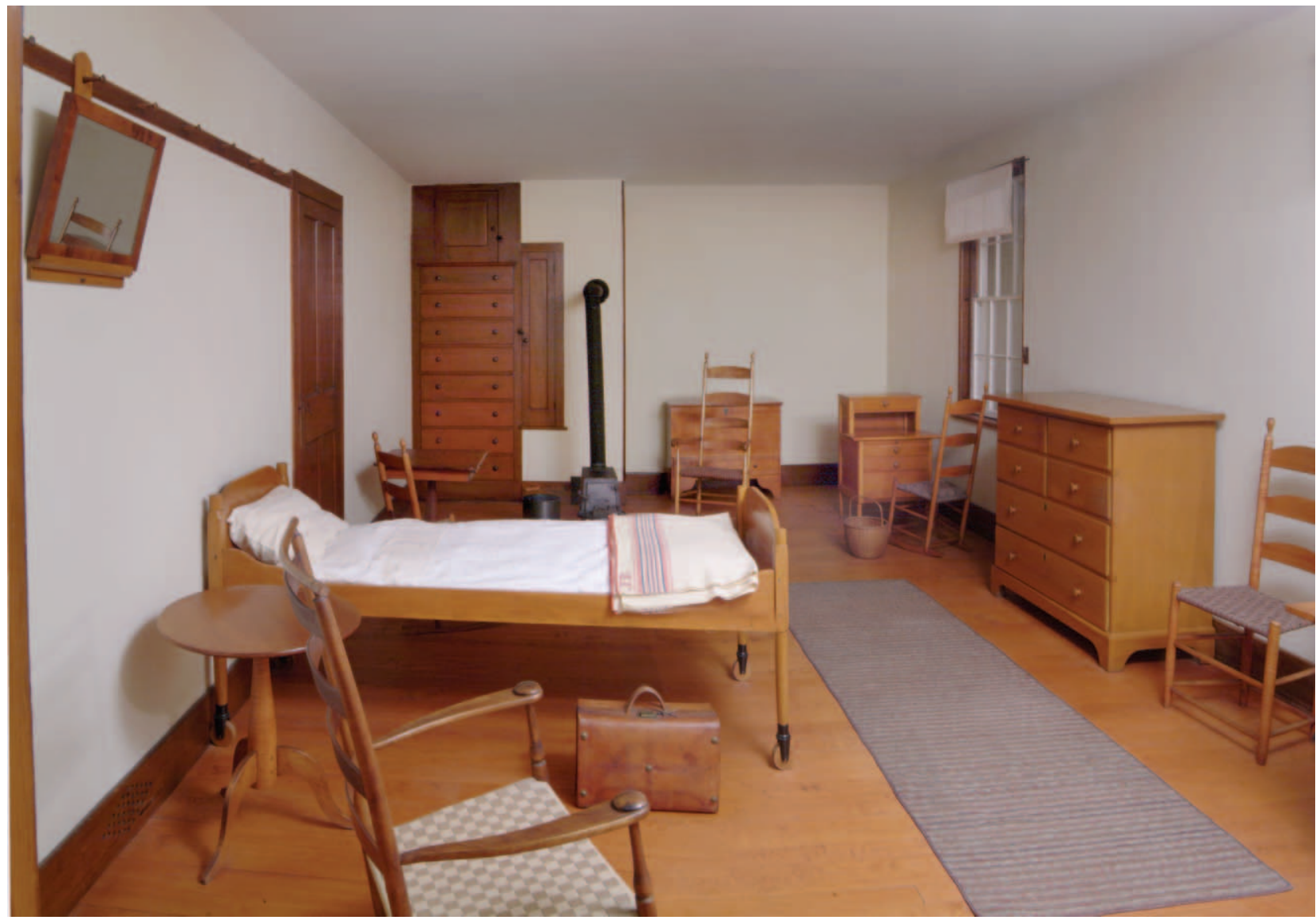

Fig. 1. Sisters' Retiring Room, Mount Lebanon, New York, ca. 1845, as installed at the Philadelphia Museum of Art, 2005. (Philadelphia Museum of Art photographs unless otherwise noted.)

mid-twentieth-century interpretation of Shaker design.

The North Family Dwelling in the Shaker Village of Mount Lebanon, New York

Mount Lebanon was officially established in 1787. ${ }^{1}$ The North Family, or novitiate order, opened in 1799 and acted as the entry point for anyone interested in becoming a Shaker. The Shakers divided their villages into spiritual families based on their commitment to the sect. Some members stayed within this family or moved to other families within the village; many of the most dedicated members eventually moved into the First or Church Family. Over the decades, the North Family became the most important fam-

\footnotetext{
${ }^{1}$ The village, originally called New Lebanon, was referred to by that name until 1861 . In that year, a post office was established at the village, so the Shakers changed the name to Mount Lebanon to distinguish their community from the nearby town of New Lebanon. In this essay, I refer to the Shaker village as Mount Lebanon.
}

ily in Mount Lebanon and, arguably, throughout Shakerdom, as some of its elders and eldresses (Frederick Evans and Anna White) became leaders of the religious sect, modernizing it and spreading its fame throughout the world. Despite their efforts, the Shakers lost members, failed to gain converts, and had to relinquish property and shut down villages. Mount Lebanon officially closed as a Shaker community in 1947 .

The North Family Dwelling was one of the oldest surviving buildings at Mount Lebanon when it was torn down. The Shakers first constructed it in 1818 as a two-and-a-half-story, woodframe structure measuring 60 by 45 feet with a gabled roof. It provided additional living space for the growing family, which had only a small, wood-frame house built in 1792. Plans produced by the Historic American Buildings Survey (HABS) in 1939 of the North Family Dwelling show that the house was originally built as a central-hall-plan structure with a single entrance used by both brothers and sisters (shown in fig. 2 as the brothers' entrance). In the late eighteenth century, as the Shakers were 


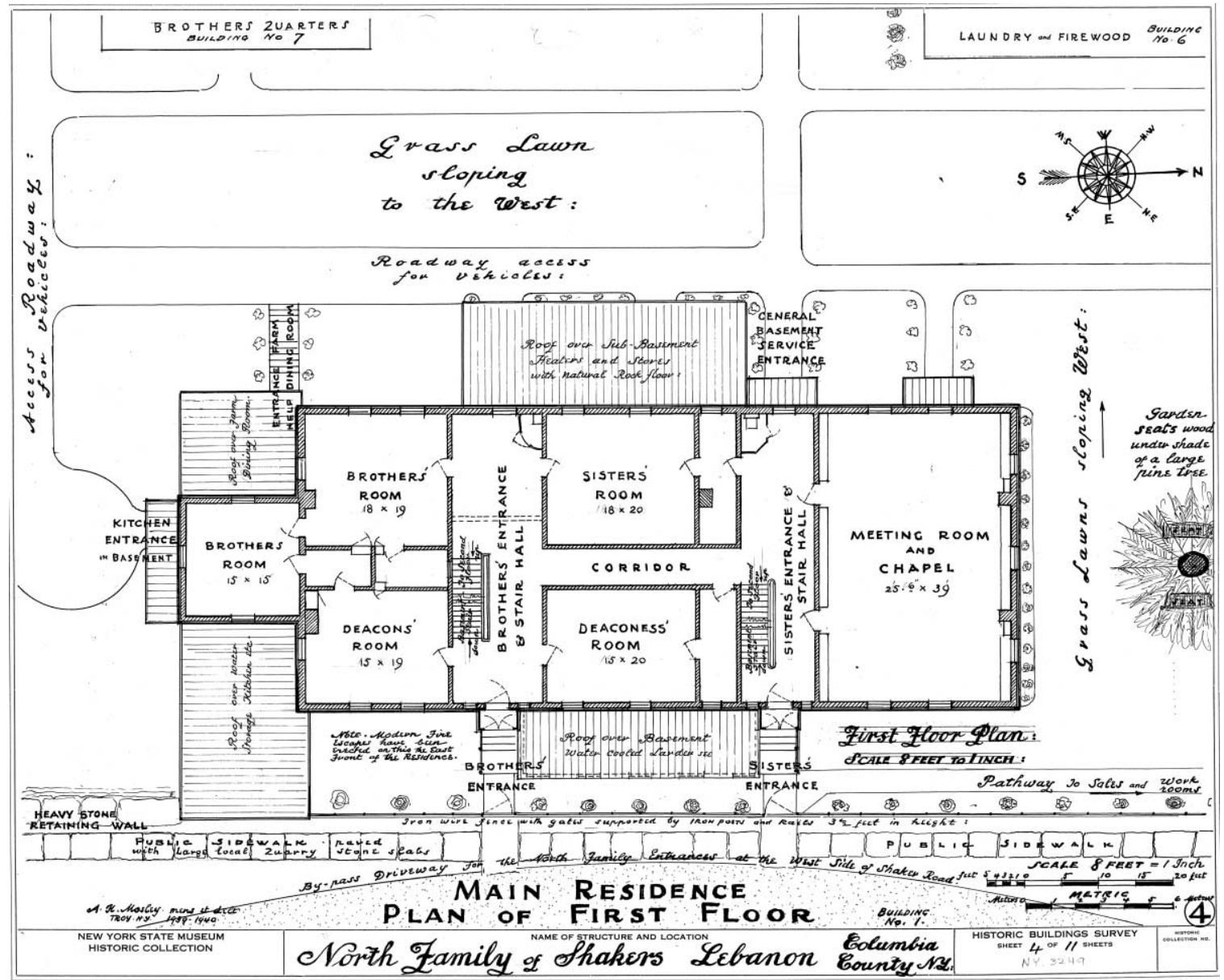

Fig. 2. First-floor plan, North Family Dwelling House, Mount Lebanon, New York, 1939. (Historic American Buildings Survey, reproduction no. NY, 1 1-NELEB.V, 24, sheet 4, Prints and Photographs Division, Library of Congress.)

organizing themselves into a religious group, the use of architectural space to separate men and women was not yet a matter of concern, although Mother Ann Lee and her early successors advocated celibacy.

As the North Family expanded, the Shakers enlarged the house, first extending it to the north in 1845 , thereby doubling its size to 120 by 45 feet, and topping it with a hipped roof. Only in the first half of the nineteenth century did Shaker leaders begin to require standardization in the arrangement of interior space within dwellings in ways that would enhance separation of the sexes. So, when the building was enlarged in 1845 , the Shakers added a separate entrance, hallway, and staircase for the sisters and isolated brothers' and sisters' retiring rooms at either end of the house. The museum's room (labeled as the "Sisters' Room" on the HABS plan of the second floor) dates from this expansion (fig. 3). The
Shakers further enlarged the building in 1863 by adding two stories and an attic and capping the structure with a very low-pitched, almost flat, gabled roof, making the dwelling one of the largest at Mount Lebanon (fig. 4). The Shakers at Mount Lebanon came to favor such box-shaped dwellings, as they provided more interior space in the attic than houses with gabled or hipped roofs. Though these dwellings were not particularly attractive, they demonstrated the Shaker tendency to favor practicality over aesthetics.

The Shakers, always interested in making their villages more efficient, working communities, introduced many innovations into their dwelling houses. An examination of the North Family's main dwelling demonstrates how the Shakers modified timber-frame construction to keep up with new building techniques. The Shakers created the frame of the original house using 1-foot-square sawn posts with 4-by-6-foot corner braces mortised, 


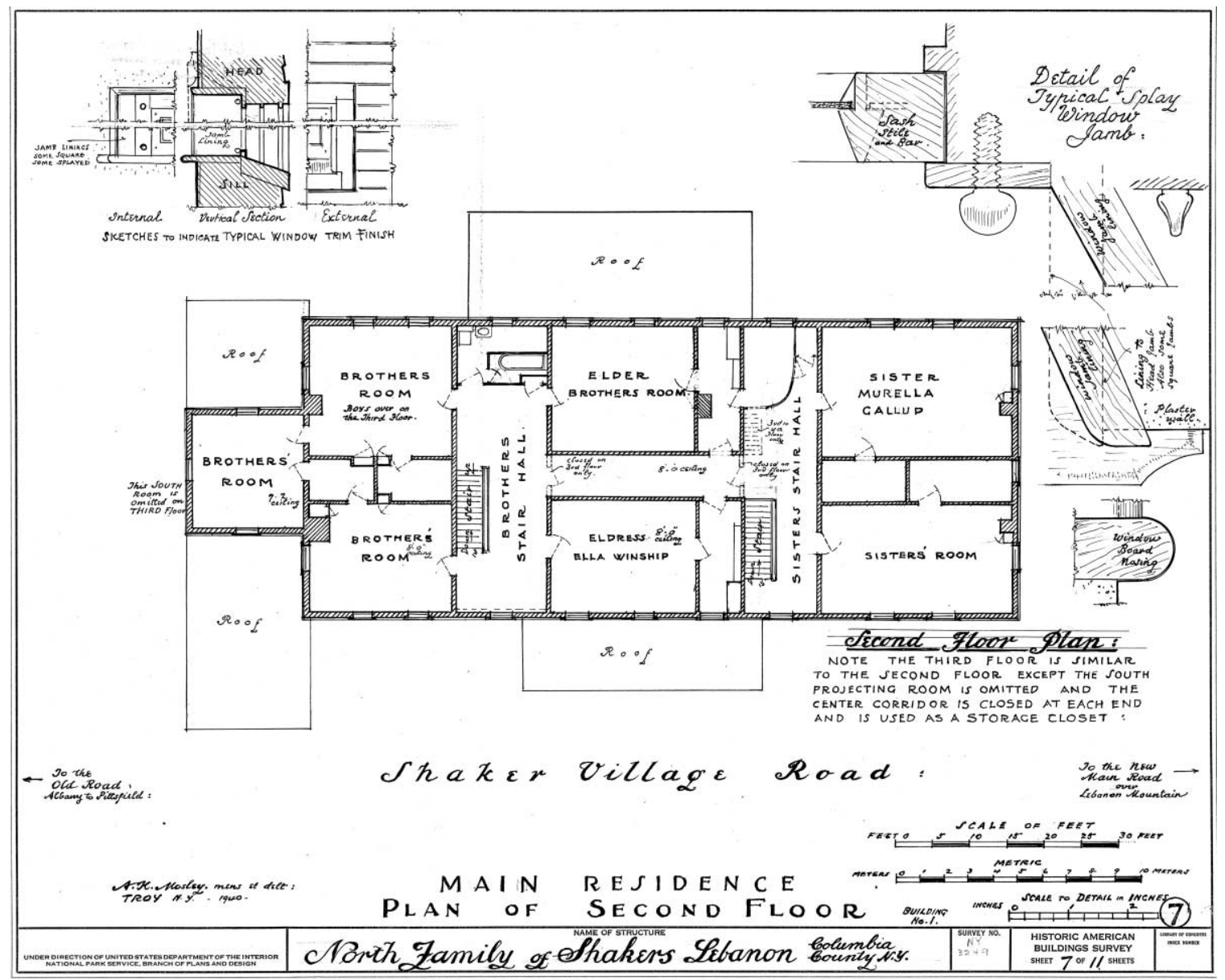

Fig. 3. Second-floor plan, North Family Dwelling House, Mount Lebanon, New York, 1939. (Historic American Buildings Survey, reproduction no. NY, 1 1-NELEB.V, 24, sheet 7, Prints and Photographs Division, Library of Congress.)

tenoned, and pegged together. Sawn 4-by-4-inch studs with 2-foot centers were then pegged to the beams. The 1845 addition shows a modification of timber-frame construction. For this phase of the building, the Shakers continued to use heavy posts and beams but placed 2-by-4-inch studs closer together, probably nailing them to the beams. The 1863 addition consisted of the third, fourth, and attic floors, using the same methods as the earlier addition. These two phases of construction reveal the Shakers' combination of elements of timber-frame construction and a modified form of balloon-frame construction by balancing aesthetic and practical considerations.

Installation of the Sisters' Retiring Room at the Philadelphia Museum of Art

In the spirit of Fiske Kimball, Garvan sought the woodwork for the Philadelphia Museum of Art to create a more authentic context for the collection of Shaker furniture and objects given to the museum in 1963 by Mr. and Mrs. Julius Zieget. Her first scheme for displaying the woodwork was a temporary installation of selected elements. In a memo to Evan Turner, the museum's director, dated January 20, 1973, she stated that the items would be built into a lightweight wall unit, "putting the pieces together in the proper scale." ${ }^{2}$ She also proposed to keep the long lengths of pegboard intact in order to protect the woodwork and to allow for the installation to be changed, if necessary. This temporary installation was never created, however, and the room's present installation became part of the new American art galleries that opened in 1976. The room's physical dimensions and that of

\footnotetext{
${ }^{2}$ Beatrice Garvan, memorandum to Evan Turner, January 20, 1973, museum files on the Shaker Room, Department of American Art, Philadelphia Museum of Art.
} 


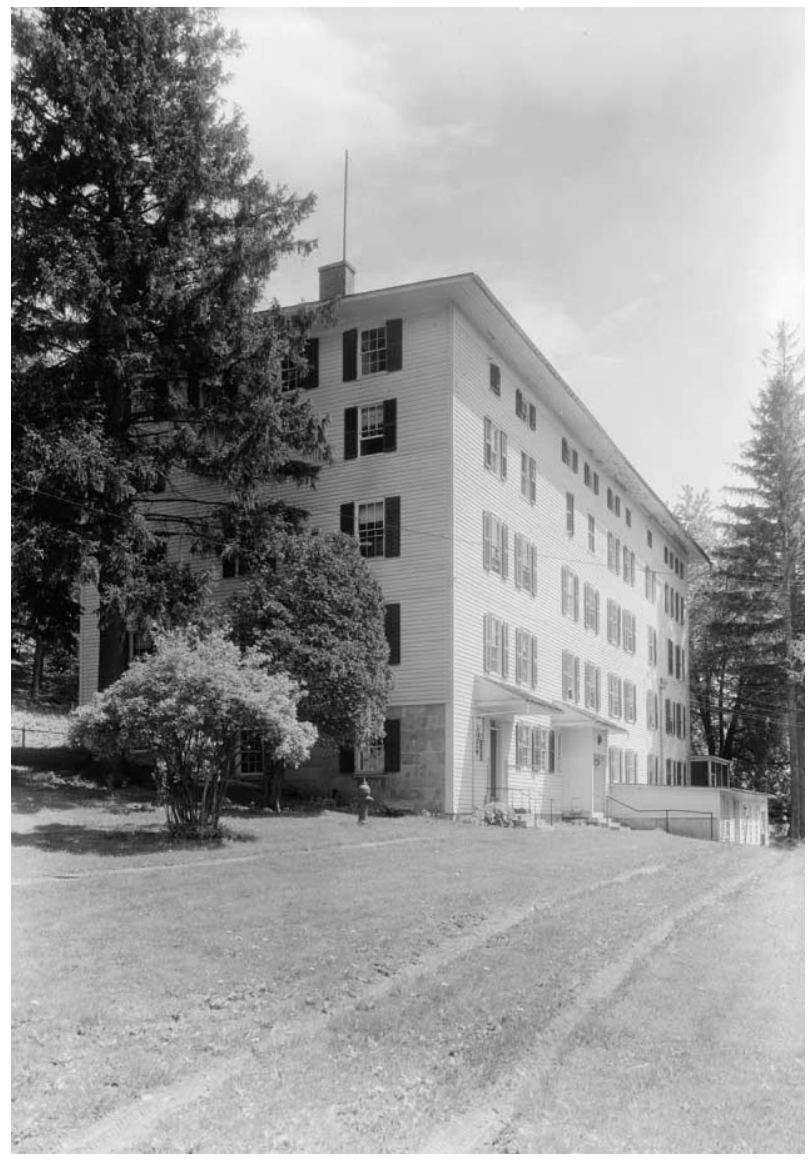

Fig. 4. West (rear) and north exterior, North Family Dwelling House, Mount Lebanon, New York, 1818-63 (demolished 1973), photo 1930. (Historic American Buildings Survey, reproduction no. NY, 1 1-NELEB.V, 24-4, Prints and Photographs Division, Library of Congress; photo, Wiliam F. Winter Jr.)

the woodwork, as well as the location of the woodwork and other architectural elements, appear to represent accurately those of the original room. The entrance door, closet door, and two windows correspond to their original locations in the North Family Dwelling. A window on the wall opposite the entrance door is missing, however.

As installed, the room reflects changes that took place within this space over time. In the 183 os the Shakers began covering their wood floors with rugs and carpets; Henry De Witt, a Shaker brother living in Mount Lebanon, painted a large carpet cloth for the ministry elders and eldresses there and a smaller one for another location. ${ }^{3}$ In May $185^{1}$ the sisters of the North Family finished hanging blinds, actually wooden shutters,

\footnotetext{
${ }^{3}$ Henry De Witt, April 28, 1838 , journal, New Lebanon, 1827-67, MS V:B-97, Shaker Manuscript Collection, Library of the Western Reserve Historical Society, Cleveland.
}

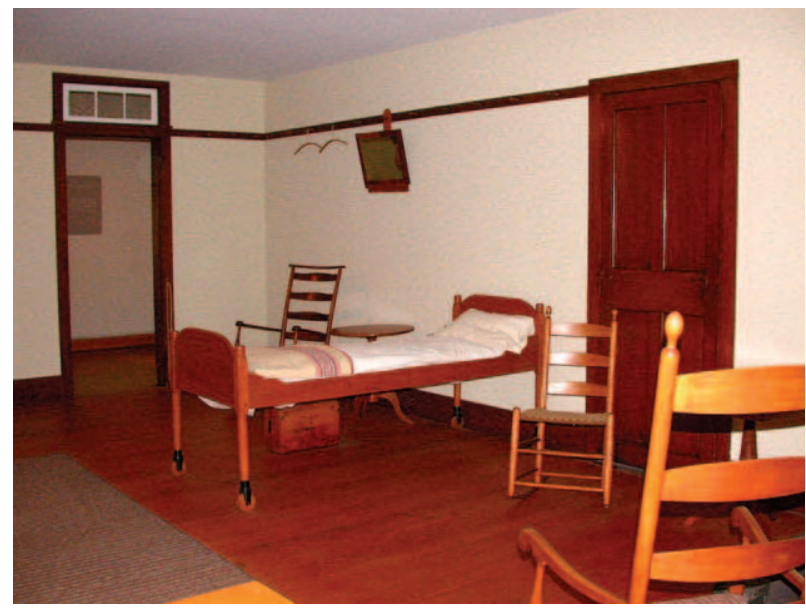

Fig. 5. Sisters' Retiring Room as installed at the Philadelphia Museum of Art, 2005.

on all the windows of the dwelling house, "the first that have been put on a dwelling house in this village." ${ }^{4}$ In January 1855 , carpenters cut windows over all the doors in the North Family's main dwelling so air could circulate from the halls into the retiring rooms (fig. 5). ${ }^{5}$ Transoms were common in large institutional structures, such as hospitals, where good air circulation was considered vital to the health of the patients. By the 1860 , sisters throughout Mount Lebanon applied leather panels to the risers of staircases in dwelling houses in order to protect the wood from being gouged by heels. ${ }^{6}$

The surface treatment of the walls and woodwork similarly was not static. Although much of the woodwork in the museum's room presently is stained, it was most likely painted originally. Over the past decade, paint analyses of Shaker interiors at Hancock Shaker Village in Pittsfield, Massachusetts; the Shaker Museum in South Union, Kentucky; Canterbury Shaker Village in Canterbury, New Hampshire; and the privately owned South Family Dwelling in Harvard, Massachusetts, show that the Shakers used different color schemes over 200 years. Much woodwork and furniture in the first half of the nineteenth century was painted, rather than stained and varnished, which became common in the late

${ }^{4}$ Sally Bushnell, May 17, $185_{1}$, "A Journal Commenced January 1st, 1848 . vol. 1," New Lebanon, $1848-5$ o, MS 10347 , Shaker Collection, Emma B. King Library, Shaker Museum, Old Chatham, New York.

${ }^{5}$ Ibid., January 18, 1855 .

${ }^{6}$ The Center Family introduced this improvement in 1867 in their new dwelling house. Robert Valentine, December 20, 1867 , Farm Deacons' Journal, New Lebanon, ${ }_{18} 8{ }^{8-67}$, MS 401, Shaker Collection, Hancock Shaker Village Library and Archives, Hancock Shaker Village, Pittsfield, Massachusetts. 
nineteenth century. The most surprising discoveries have revealed evidence demonstrating that the Shakers used vibrant colors-chrome yellow, red ocher, and Prussian blue, for example-for wood trim, built-in cupboards and drawers, doors, and floors in dwelling houses and meeting houses. ${ }^{7}$

The stripped and stained surfaces of the museum's room are consistent with the condition of the furniture collection displayed in it and reflect a specific vision of Shaker life popular during the middle quarters of the twentieth century. This stark aesthetic does not provide an accurate picture of how these interiors looked or functioned over time. Instead, it perpetuates ideas of timeless simplicity and perfection that were, in part, the creation of twentieth-century photographers, such as Charles Sheeler and William F. Winter, who nostalgically concentrated on the stark simplicity of Shaker forms, rather than on the reality of interiors that would have held Shaker-made pieces, as well as objects acquired from the outside world. In fact, Winter admitted to moving Shaker pieces to obtain the plain look he wanted. ${ }^{8}$

The Metropolitan Museum of Art acquired its retiring room-the only other surviving room from the North Family Dwelling-in 1973 and installed it in 1981. The Metropolitan Museum's room stood across the hall from the Philadelphia Museum's room and is slightly larger. The HABS plans identify it as Sister Murella Gallup's room (see fig. 3). As with the Philadelphia room, this one appears to be installed accurately with no missing or altered woodwork or other architectural elements. The Metropolitan Museum recreated the plaster walls and their original white finish, copying those of the top floor of the 1830 Brick Dwelling House at Hancock Shaker Village. ${ }^{9}$ The interior of this dwelling's top floor remains largely untouched, so the finish of the plaster walls provides an accurate model.

\footnotetext{
${ }^{7}$ See Christian Goodwillie, "Coloring the Past: Shaker Painted Interiors," Antiques 168 (September 2005): 81-87.

${ }^{8}$ For more information on Winter, see Stephen J. Stein, The Shaker Experience in America: A History of the United Society of Believers (New Haven, CT: Yale University Press, 1992), 376; David A. Schorsch, The Photographs of William F. Winter, Jr., I899-I939 (New York: D. A. Schorsch, 1989). For deeper analyses of Shaker furnishings, see Julie Nicoletta, "Structures for Communal Life: Shaker Dwelling Houses at Mount Lebanon, New York" (PhD diss., Yale University, 1993), 203-19; William D. Moore, "Interpreting the Shakers: Opening the Villages to the Public, 19551965," CRM: The Journal of Heritage Stewardship 3, no. 1 (Winter 2006): $53-54$.

${ }^{9}$ Letter from Alice Cooney Frelinghuysen to Neil McLaughlin, November 24, 1982, Shaker Room Correspondence, American Wing, Metropolitan Museum of Art, New York.
}

Recommendations for Reinstallation

When reevaluating its Shaker room, the Philadelphia Museum of Art should not isolate it with examples of American folk art but, rather, recontextualize it to demonstrate how the Shakers were influenced by and, in turn, influenced architecture and design of the outside world. Ideally, the museum would relocate the room adjacent to other period rooms and objects, both high style and vernacular, from the same time period in order to present the Shakers as keen observers and consumers of mainstream design even as they claimed to reject much of it, particularly in the early nineteenth century. With the current location of the museum's Shaker objects, museum visitors have to cover much ground in order to build a larger context for Shaker design. Because relocating the room seems unlikely, however, a reinstallation of the room should consider ways to provide a larger historic and aesthetic context for the museum's Shaker collection.

When reinstalling the Shaker room, the museum should consider furnishing the room with items more typical of the 184 os and later, a mix of Shaker furniture and other non-Shaker-made pieces the sect would have used at the time, and include examples of non-Shaker objects in the adjacent display area so visitors can compare the Shakers' material culture with more mainstream examples. The museum could also use wall labels or more interactive devices, such as a touch screen in the gallery or downloadable applications for smart phones and tablets, to help viewers envision how the Sisters' Retiring Room changed over time as the sect lost members and became more worldly. Such interpretive devices could also be used to demonstrate how our understanding of the Shakers and their world has changed over the past century. A rethinking of the Shaker period room will provide an opportunity to present the Shakers not as exceptions but, rather, as part of a larger movement in American design, the influence of which is still being felt in the United States and Europe.

The Sisters' Retiring Room at the Philadelphia Museum of Art is significant as a rare remnant of an important Shaker building now lost. The architectural details provide a window into how such rooms once appeared, as well as how they have been interpreted during the twentieth century. In addition, ongoing efforts to preserve and study the North Family buildings at Mount Lebanon will make the survival of this period room even more 
important as new discoveries, such as paint analyses and reinterpretations of Shaker material culture, provide a clearer picture of how Shaker buildings and interiors changed over time. In 2004, the Shaker Museum and Library in Old Chatham, New York, not far from Mount Lebanon, purchased the surviving ten North Family buildings and the 30 acres of land on which they stand, in addition to the barrel-roofed meetinghouse in the center of the village, to serve as the new home of the museum. Over the past several years, the museum has undertaken stabilization and rehabilitation projects on the Wash House, the Granary, the Brethren's Workshop, and the walls of the Great Stone Barn, as well as restoration of the surrounding landscape. The recently renamed Shaker Museum/Mount Lebanon is in the process of relocating its collections to the North Family site, where it will provide new opportunities to examine Shaker life and design. This work undoubtedly will affect the future exhibition and interpretation of Shaker period rooms, such as the one at the Philadelphia Museum of Art. 